future of European experiments for the NASA vehicle. According to ESA, work on those experiments is already well advanced and substantial sums of money, which will have been spent in vain if NASA's decision stands, have already been committed. The total cost to completion of the two spacecraft is an estimated $\$ 140$ million, $\$ 100$ million of which is already accounted for.

Judy Redfearn

\section{European fusion}

\section{JET's ambition}

JET, the joint European tokamak nuclear fusion experiment, may cost another 400 million European units of account (EVA) ( $£ 216$ million) if first the JET Council - which oversees the project - and then the European Commission agree. The money would be spent over five years, beginning in 1982, and would extend JET to its full design performance, including bulk ignition of a deuteriumtritium plasma. "If they want the results, they'll have to pay" said Dr Hans-Otto Wüster, director of JET, of the European governments last week.

The original cost of basic JET was 185 million EUA at January 1977 prices. Inflation in Britain, coupled with the strength of the pound sterling and a serious underestimate of the cost of diagnostic equipment, has pushed that basic price to something nearer 300 million EUA; but even so the proposed extension would more than double the total cost. Dr Wuster, however, points out that the extra cost is only twice the annual budget of the CERN laboratory in Geneva.

The rush to extend JET is occasioned by two factors. First, machines like JET seem to have a better chance of reaching ignition, the nuclear burning of the plasma, than when they were designed in the early 1970s. Second, the European Council of Ministers has asked for a proposal for fusion research in Europe for the next five-year period, 1982-86, by 1 July this year.

Competition with the United States is also in mind. Princeton's Tokamak Fusion Test Reactor is due to begin experiments in 1982 , and the somewhat larger JET in early

\section{JET upgraded}

The extension of JET to full design performance would involve increased magnetic confinement fields, additional heating of the plasma, facilities for storing and handling tritium, and remote handling equipment for experiments. Specifically, the peak toroidal field coil power would be increased from $250 \mathrm{MW}$ to $380 \mathrm{MW}$; total magnetic field at plasma centre $27.7 \mathrm{kG}$ to $34.5 \mathrm{kG}$; plasma current from 3.8 MA to 4.8 MA; and additional heating power from 4-10 MW to $25 \mathrm{MW}$.

Robert Walgate
1983. Princeton is being pushed hard by the US Department of Energy to try ignition early. If all went well, JET's initial nonnuclear plasma experiments would then look pretty tame. On the other hand, if either laboratory is too hasty in introducing radioactive tritium, repeating early experiments will be very difficult, requiring remote handling and radiation protection.

Important plasma physics problems remain to be solved. Present optimism arises because two predicted limits on plasma containment have not been observed in existing small tokamaks. "Trapped particle instabilities" were expected to set in at temperatures above 30 million $K$, but the smaller Princeton tokamak has reached 70 million $\mathrm{K}$ without seeing them. And the ratio of plasma pressure to magnetic pressure was thought to be limited to about 1 per cent, but values of 8-9 per cent have been reached. While experimentally encouraging, these results are theoretically puzzling, so the JET and Tokamak Fusion Test Reactor regions may still hold surprises.

Dr Wüster is therefore cautious, offering 3-4 years of plasma at JET before attempting ignition around 1987. But the bulk of the spending on "extended performance" would have to be undertaken in 1982-86. In January, the JET Council gave Wüster a 400 million EUA guideline for the extended performance, and asked him to say what he could do with that. If, this month, his proposals are adopted, it will be for the European Commission to consider whether to include it as part of the 1982-86 research programme.

Conflicts between the interests of the national laboratories and money-hungry JET seem likely to be resolved at JET Council level; but the commission must also test the interest of governments, for which reason it has set up a new committee - the Consultative Committee for Fusion Programmes - which will be dominated by the representatives of government departments from whose coffers the money must ultimately be found.

The commission has also established an expert panel, the European Fusion Review Panel, to make recommendations for a long-term programme, beyond the present generation of machines. This panel will also report to the commission before July, in time to influence the final commission proposal.

One question to be dealt with is whether Europe is wise to commit itself so heavily to one design of fusion device, the tokamak. In the United States, there is also substantial work on the potentially simpler magnetic mirror confinement and inertial confinement. Wüster says that it makes sense to push ahead with the device that will most quickly yield ignition, so as to win practical experience of the problems of operating fusion reactors of all types. We shall see whether the European Fusion Review Panel agrees with him.

\section{United States budget}

\section{More cuts}

\section{Washington}

True to its political convictions, when full details of its proposed budget cuts are announced next week, the Reagan Administration is expected to eliminate virtually all the federally sponsored programmes initiated by President Carter to stimulate innovation in private industry.

President Carter's initiatives were the result of a broad-ranging, eighteen-month study largely instigated by the Office of Science and Technology Policy. Recommendations were made by eight independent advisory committees, and submitted to the White House with proposals from individual federal agencies.

From these, a package of 32 proposals was eventually accepted and announced by $\mathrm{Mr}$ Carter in November 1979. Although criticized at the time for not going far enough, it was generally agreed that the proposals made up a modest set of experimental and exploratory approaches aimed at bringing industry, government and the universities closer together.

The interventionist approach which the new programmes embodied, however, has found little sympathy with the new Administration, which sees its principal strategy for stimulating innovation as improving the financial incentives for investment, not direct federal participation.

The Administration will therefore be expected to drop support for any future cooperative generic technology centres, even though specific legislation setting up these centres was approved by Congress last year, and $\$ 5$ million allocated to their support (Nature 286, 195; 1980). From the three centres initially proposed, only one, in Detroit, is likely to survive as plans were agreed before the election, although even this is uncertain since it will depend on the centre's ability to raise matching funds from industry.

Other projects previously under development in the Commerce Department and now expected to be phased out include proposals to establish state-based Corporations for Innovation Development to help entrepreneurs gain access to investment capital, and the new Office of Technology Strategy and Evaluation.

It is also rumoured that the new Administration may not seek a successor to Dr Baruch, who as Assistant Secretary for Productivity Technology and Innovation was responsible for science and technology programmes within the department. This would be opposed by Congress, which spent much time last year discussing the Carter Administration's initiatives, and supported their general thrust.

Another of Mr Carter's initiatives which will be overruled is the Co-operative Automotive Research Project (CARP), originally proposed by Transportation Secretary Mr Brock Adams as a means of 
generating joint government and industry support for long-term research, and already approved by Congress with a budget of $\$ 12$ million for the first year. In his budget proposals of two weeks ago, $\mathrm{Mr}$ Reagan said that "federal financing of long-term research to benefit a particular industry is an inappropriate allocation of federal funds". He is proposing to rescind the full amount appropriated by Congress for the current year, and to terminate the whole programme.

At the National Science Foundation, schemes for encouraging greater technological innovation in small businesses, and for forging closer links between industry and universities, will remain in force, but will not get the substantial increase in funding that the Carter Administration had promised as part of its innovation package.

Support for small industries innovation, for example, was to have been almost doubled, from $\$ 7.5$ million to $\$ 14.5$ million next year, following its earlier success, but will now be cut back. So too will increased funds for engineering education, but the proposed 20 per cent increase for engineering research is likely to remain.

In contrast with the cuts being proposed in measures which would increase federal involvement in the innovation process, other steps initiated by Mr Carter to reduce the federal role have been warmly endorsed and built upon by the new Administration.

Efforts to reduce the burden of health, safety and environmental regulations, for example, have already been expanded. As expected, $\mathrm{Mr}$ Reagan has proposed, along with his budget reductions, a set of regulatory reforms which would submit all new and existing regulation to strict costbenefit analysis.

Similarly, additional patent reform legislation has already been introduced into the new session of Congress which would expand on $\mathrm{Mr}$ Carter's patent reform bill giving universities and small businesses patent rights on federally funded research.

David Dickson

\section{UK research councils}

\section{Allen accused}

The UK Science Research Council is being hauled over the coals for sloppy bookkeeping. Its chairman, Sir Geoffrey Allen, is to appear before the Public Accounts Committee of the House of Commons on 17 March to explain irregularities in the council's funding in the financial year 1979-80. Details are hard to obtain because the council, usually frank, is saying nothing for fear of offending parliamentary privilege.

Part of the problem stems from the cash bonus that Mrs Shirley Williams, then Secretary of State for Education and Science, obtained for the research councils in 1978. The council's share was $£ 33$ million over the four financial years
1979-83. A circular was thereupon sent around universities asking for applications to the council to replace worn-out equipment: truck-loads of applications followed, worth $£ 37$ million, of which the council awarded $£ 7.5$ million. In the event, a change of government followed, funds were cut and the council received only $£ 5$ million.

Another question mark hangs over the university grants current in March 1980, which represented an increase in value of $£ 31$ million ( 34 per cent) over the previous year. There appears to be no indication that this large increase was planned. The exact amount of overspending remains unclear, but much of the money was spent by the Science Board (responsible for such topics as physics of solids and liquids, chemistry and biology). The new Spallation Neutron Source at the Rutherford-Appleton Laboratory at Chilton seems to have been a principal beneficiary.

Other misdemeanours are procedurally more serious. The Auditor General, Sir Douglas Henley, has already complained that the postponement of certain payments into the 1980-81 financial year, as part of an attempt to alleviate the financial deficit, contravenes government regulations. The Public Accounts Committee will also, no doubt, be asking about the council's calculation that the capital value of a site near Slough, yet to be vacated, could be regarded as a part of the income for 1979-80.

The council appears to have been the victim of government financial vagaries combined with inflexible accounting procedures. But the extent to which the problems are also self-generated will not be clear until 17 March.

Sir Geoffrey Allen, formerly the council's accounting officer, came to the end of his spell as chairman in October. The name of his successor is expected to be announced within a few weeks.

Philip Campbell

\section{Soviet research}

\section{More home growth}

The new Soviet Five-Year Plan calls for all branches of the economy to be brought up to the "most up-to-date levels of science and technology". Just how to do this is clearly causing the Soviet leadership considerable anxiety. At the Twenty-Sixth Congress of the Communist Party of the Soviet Union last week, Mr Brezhnev called on the whole scientific establishment to reassess the research and development basis of Soviet industry and to propose ways of regrouping the "scientific forces".

Not only the Academy of Sciences and the State Committee for Science and Technology should take part in this audit, said Mr Brezhnev, but also the sciencebased industries, including defence. Since Soviet military research is organized quite separately from the civil sector, this last proposal suggests genuine concern, not simply congress window-dressing.

Mr Brezhnev singled out a number of fields of technology where "impermissible sluggishness" had led to delays in implementing "promising developments" - the continuous casting of steel, powder metallurgy, custom-built DC transmission lines and high-strength artificial fibres. Falling behind foreign competitors, he said, leads to massive expenditure of foreign currency for equipment and technology which the Soviet Union could have produced at home. Soviet potential technological self-sufficiency has been a feature of propaganda speeches since the January 1979 United States embargo. Mr Brezhnev's speech, however, referred rather to one of the major concerns of Soviet research policy: why is there often so long a gap between obtaining a new result and implementing it in production?

$\mathrm{Mr}$ Brezhnev suggested two possible lines of reorganization, which appear mutually contradictory. On the one hand, he stressed the Central Committee's support for an increased responsibility for the Soviet Academy of Sciences, and argued a "flexible and mobile" organization of research that would not tolerate "fruitless laboratories and institutes", but would respond "attentively"' to the needs of scientists for equipment, instruments and pilot plant facilities. Taken in isolation, these remarks suggest more scope for serendipity and the capacity to switch rapidly from one line of research to a more promising alternative.

Mr Brezhnev went on the say, however, that the major sciences (including basic research) should concentrate more on solving "key national economic questions" and "discoveries capable of making genuinely revolutionary changes in production". The formulation of these tasks, he said, is the task of the central planning bodies and the State Committee for Science and Technology. The exact spheres of competence of the Academy and State Committee are frequently difficult to define, and Mr Breszhnev's speech does not make the issue easier. The previous Congress (1976) had made the Academy responsible for coordinating all science throughout the country, and although, to judge from the report to Congress of $\mathrm{Dr}$ Anatolii P. Aleksandrov, the Academy's president, much still remains to be done, there is no suggestion that the task should be taken out of the Academy's hands.

Dr Aleksandrov's report, moreover, reviewed a wide range of recent achievements, from particle physics and cosmology to the utilization of Estonian shales and the need to develop coal liquefaction and gasification techniques. Academy scientists, he said, have made notable advances in thermonuclear fusion, and in prolonging the life of agricultural machinery.

Discussion of future plans, at a Congress 